\title{
Standard učitelské profese ve Skotsku
}

\author{
Jan Voda \\ Univerzita Karlova v Praze, Pedagogická fakulta
}

\begin{abstract}
Abstrakt: Kvalita vzdělávání je přímo úměrná kvalitě učitelů a ta se do velké míry odvíjí od jejich vzdělání, celoživotního učení a profesionalizace. Znakem rozvinuté profesní kultury je mimo jiné existence profesního standardu. Zavedení standardu je nicméně náročný a komplikovaný proces, který vyžaduje značné politické odhodlání, cílevědomost i odvahu. V příspěvku nabízíme širší pohled na školskou politiku ve Skotsku, kde se s těmito problémy dokázali v pozoruhodně krátké době vyrovnat, dosáhli široce sdíleného konsensu, přijetí a spolupráce, jejímž výsledkem jsou revidované Standardy platné od srpna 2013.
\end{abstract}

Klíčová slova: kvalita, učitel, profesní standard, školská politika, celoživotní učení, Skotsko

\section{The Professional Standards in Scotland}

Abstract: The quality of education is directly linked to the quality of teachers and this mainly depends on their education, lifelong learning and professionalization. The feature of developed professional culture, among others, is the existence of professional standards. To introduce the standard, however, is quite a difficult and complicated process which requires considerable political commitment, determination and courage. In this paper, we offer a broader view of education policy in Scotland, where they reached - in a remarkably short amount of time a widely shared consensus of acceptance and cooperation. This resulted in revised standards that were applied in August of 2013.

Keywords: quality, teacher, professional standard, school policy, career-long learning, Scottland

Motto: „Skotsko má pevný vzdělávací systém s tisíci angažovaných a pracovitých učitelů, kteří se snaží dovést naše děti a mládež k nejlepším možným výsledkům." (z programového prohlášenín Národní skupiny partnerů; NPG, 2012 s. 4)

Učitelská profese zaujímá významné místo v sociálních a politických diskusích v mnoha zemích. Na představitelích školské politiky, na profesních organizacích a na institucích vzdělávajících učitele leží odpovědnost zajistit, aby učitelé ve všech školách byli dobře připraveni pro svou náročnou práci. S tím souvisí odpovědnost zavést takové systémy, které umožňují definování a prosazování žádoucích profesních kvalit a jejich standardů (Spilková, 2010).

Standardy představují soubor hodnot a znaků umožňujících spravedlivé, spolehlivé a smysluplné posouzení kvality profesního výkonu (Ingvarson et al., 2006; Spilková, 2008; CEPPE, 2013). V procesu vytváření standardů by se tvůrci měli snažit identifikovat a pochopit charakteristické rysy a aspirace učitelské profese - unikát- 
88 ní věci, které kvalitní učitelé znají a dělají. Standardy by tak měly být vyjádřením znaků profesního výkonu, které jsou v rámci profese a ve společnosti obecně nejvíce ceněny. Proces tvorby standardu $v$ tomto smyslu má sjednotit učitele kolem sdílených ideálů a hodnot a v praxi podporovat sladění rozdílných př́stupů. Tvưrci standardu musí usilovat o formulaci vize kvalitního vyučování, která bude určující pro podrobnější vyjádření, co by učitelé měli vědět, jaké hodnoty zastávat, co by měli být schopni dělat - to vše s cílem vytvářet kontext právě pro takovou kvalitu výuky.

Cílem příspěvku je informovat o stavu řešení standardů učitelství ve Skotsku po jejich revizi v roce 2013 a zasadit tyto informace do širšího národního kontextu, $v$ němž se formoval koncept kvality učitelů ve Skotsku a požadavek celoživotního učitelského vzdělávání. Základním výzkumným př́stupem pro shromáždění relevantních informací byla obsahová analýza školskopolitických dokumentů Skotska a studium vlastních standardů učitelské profese ve Skotsku.

\section{Skotský národní kontext}

Většina z klíčových principů/hodnot, na nichž je vzdělávání ve Skotsku postaveno, vychází z dlouholeté tradice. Právní předpisy se zde týkají především správy a organizace školského systému. Vlastní principy vzdělávání jsou částečně odrazem vzdělávací politiky vlády, dílem představují konsensuální názor odborníků zachycený v mnoha analytických zprávách a pedagogických dokumentech. Pěticí strategických cílů vláda vyjádřila svoji vizi budoucnosti země (National performance framework, 2011): Skotsko, které je (1) bohatší a spravedlivější (wealthier and fairer), (2) chytřjší (smarter), (3) zdravější (healthier), (4) bezpečnější (safer) a (5) silnější a zelenější (stronger and greener). Ve sféře vzdělávací politiky je určující zejména strategický cíl „chytřejší Skotsko“ a z něho odvozené cílové stavy a ukazatele. Chytřejší Skotsko je artikulováno posílením šancí člověka být úspěšný od rané výchovy až po celoživotní vzdělávání a dále směřováním k větší sociální a hospodářské soudržnosti, již je dosahováno zodpovědnou péčí o to, aby vzdělání jako významný faktor přispívalo $\mathrm{k}$ budování silnějších a více houževnatých rodin a komunit. Představa „chytřejšího Skotska“ je konkretizována směřováním k naplnění 16 národních cílových stavů (outcomes) shrnutých do následujících výroků:

- Jsme vzdělanější, zkušenější a úspěšnější národ, pověstný pro náš výzkum a inovace.

- Naši mladí lidé jsou úspěšní učící se jedinci (learners), seběvědomé osobnosti, efektivní přispěvatelé (contributors) a odpovědní občané.

- Naše děti mají nejlepši start do života a jsou připraveny k úspěchu.

- Zlepšili jsme životní šance pro ohrožené děti, mládež a rodiny. (www.scotland .gov.uk)

Jedním z nástrojů takto pojaté vzdělávací politiky je kurikulární reforma artikulovaná v dokumentu Curriculum for excellence (Scottish Executive, 2004). Ten 
je obecně považován za vývojový mezník ve skotském vzdělávání, oslavován jako „jeden z nejambicióznějších programů transformace vzdělávání, který kdy Skotsko mělo“ (Scottish Government, 2008, s. 1). Curriculum for excellence je radikální především $v$ tom, že vyžaduje posun pedagogické práce ve třídě $k$ většímu důrazu na výuku orientovanou na žáka (pupil centred). Současně s tím je oživen pohled na učitele jako na profesionálního spolutvưrce kurikula, aktéra změny a položen důraz na flexibilní plánování soudržných, pružnějších a obohacenějších osnov pro žáky od 3 do 18 let. Nové kurikulum si klade za cíl zajistit, aby všichni mladí lidé ve Skotsku mohli rozvinout své znalosti, dovednosti a vlastnosti (attributes), které budou potřebovat pro osobní růst při studiu i v zaměstnání, nyní i v budoucnu:

Naše aspirace jsou umožnit všem dětem rozvinout svůj potenciál jako úspěšní studenti (learners), sebevědomí jedinci, odpovědní občané a platní přispěvatelé k životu ve společnosti. (Scottish Executive, 2004, s. 6)

Tato věta je vyjádřením čtyř ústředních kompetencí (capacity). Kurikulum zahrnuje veškerou zkušenost učících se nabytou prostřednictvím jejich vzdělávání, kdekoli jsou vyučováni. Popis této zkušenosti je $v$ dokumentu strukturován do čtyř oddílů: (1) vzdělávací oblasti a vyučovací předměty, (2) mezipředmětové učení, (3) pozitivní étos a klima respektu a důvěry, založené na společných hodnotách $v$ celé školní komunitě a (4) př́ležitosti pro osobní úspěch ve tř́dě a mimo ni, což dává žákům pocit spokojenosti a posiluje jejich motivaci, odolnost a spolehlivost.

Curriculum for exellence ( $\mathrm{CfE}$ ) jsme zde podrobněji popsali proto, abychom ilustrovali, jaké úkoly před skotskými učiteli stojí. Navzdory pregnantní rétorice strategických dokumentů totiž také ze skotských škol zaznívají určité pochybnosti. Např. internetový magazín The Telegraph uvedl v dubnu 2012: „Skotští učitelé jsou ,zmítáni v temnotách', protože nové kurikulum je nejasné $v$ tom, co by se děti ve třídě měly učit..."1 Vedle obdobných mediálních prohlášení jsou k dispozici i studie (Baumfield, \& Menter, 2008; Baumfield, Livingston, \& Menter, 2009). Odborníci z University of Stirling (Priestley \& Minty, 2012) dospěli prostřednictvím 31 hloubkových polostrukturovaných rozhovorů a internetového dotazníku $(\mathrm{N}=716)$ $\mathrm{k}$ tomuto závěru:

Náš výzkum nás přesvědčil o tom, že Skotsko má vysoce profesionální a motivované učitele, nicméně, takový závazek (rozuměj tvorba nového kurikula) je pro mnoho lidí obtížný z důvodu nejasnosti a nesoudržnosti v dokumentech, jimiž se řídila implementace $\mathrm{CfE}$, a pro nedostatek systematických postupů pro přemostění realizační mezery mezi politikou a praxí. (s. 9)

Tato skutečnost se nám jeví jako alarmující, nebot' odhaluje dosud nedořešený problém v samém jádru skotské vzdělávací reformy.

The Telegraph, 11. 4. 2012, http://www.telegraph.co.uk/news/politics/9198231/Scottish -teachers-floundering-over-Curriculum-for-Excellence.html. 


\section{Klíčové fáze transformace $v$ dokumentech skotské vzdělávací politiky}

V našem výkladu budeme sledovat implementaci stávajících revidovaných standardů učitelství od prvního explicitního impulzu v tzv. Donaldsonově zprávě z prosince 2010 (Donaldson, 2011) až po jejich oficiální zavedení v srpnu 2013. Přesto je nutné vnímat tento ohraničený výsek v širším kontextu a v sepětí s dřívějšími koncepcemi skotského vzdělávání. Mezi ně patři např. strategický dokument $A$ teaching profession for the 21st century (Scottish Executive, 2001) nebo tzv. McCormacova zpráva² o zaměstnanosti učitelů ve Skotsku (Scottish government, 2011).

Současně musíme českému čtenáři připomenout, že v preprimárním, primárním a sekundárním skotském školství zastávají rozhodující úlohu místní samosprávy (local government councils). Tyto samosprávy, kterých je ve Skotsku 32, mají prímou odpovědnost za školy, zaměstnávání pedagogických pracovníků, poskytování a financování většiny vzdělávacích služeb a implementaci skotské vládní politiky ve vzdělávání. Zákon z roku 2000 (The standards in Scotland's schools etc. act) zakotvuje povinnost místních samospráv usilovat o zlepšování kvality školního vzdělávání a zveřejňovat roční plány rozvojových cílů škol, které spravují (EURYPEDIA).

Na národní úrovni existuje ve Skotsku několik agentur pro rozvoj vzdělávání zřízených k tomuto účelu skotskou vládou, které jsou využívány pro konzultace v otázkách kurikulární politiky, učení a vyučování a hodnocení. Členy těchto orgánů jsou pedagogičtí pracovníci z různých druhů vzdělávacích zařízení a zástupci mimo školství. Pro účely tohoto příspěvku je nutné jmenovat dvě instituce: Nejvyšší skotská rada pro vyučování (The general teaching council for Scotland - GTCS) je ze zákona odpovědná za udržování registru učitelů (bez zápisu do registru nemůže nikdo ve Skotsku vyučovat) a za zavedení a monitorování profesních učitelských standarů. Ministr školství musí podle téhož zákona projednávat s GTCS všechny záležitosti týkající se vzdělávání učitelů. Od dubna 2012 je GTCS zcela autonomní profesní organizací. Druhou z národních institucí je Learning and teaching Scotland (LTS), jejímž prostřednictvím jsou zastoupeny různé vzdělávací zájmy. LTS poskytuje poradenství ohledně školního kurikula, výuky, nových technologií a efektivnější vzdělávací praxe. (EURYPEDIA)

Jak jsme uvedli shora, východiskem našeho zkoumání je obsáhlá analytická zpráva dr. Grahama Donaldsona Report of a review ${ }^{3}$ of teacher education in Scotland (Zpráva o přezkumu vzdělávání učitelů ve Skotsku; Donaldson, 2011), která vešla ve

2 Kennedy, Barlow, \& MacGregor (2012) provedli v McCormacově zprávě důkladnou obsahovou analýzu pojmu „profesionalita“. Upozorňují, že tento výraz se v dokumentu vyskytuje celkem 13, a to výhradně v souslovích „zlepšování profesionality, zvyšování profesionality, posílená profesionalita, rozšířená profesionalita, vzrůstající profesionalita“. Autoři poukazují, že „použití této terminologie naznačuje, že učitelé nejsou v současnosti (2011 - pozn. autor) profesionální dostatečně, anebo nejsou profesionální ,správným‘ zpưsobem“. (s. 6) Argumentují, že v této souvislosti je signifikantní řada nedořešených otázek: „Kdo zlepšuje profesionalitu? Jaký koncept profesionality má být posilován? Proč potřebuje být profesionalita učitelů zvyšována právě nyní?“ (tamtéž)

3 Odkaz na „Review“ v názvu zprávy propojuje Donaldsonovy aktivity s dřivější agendou Skotské vlády Review of Teacher Education in Scotland (RATES). Cílem programu bylo přezkoumat, zda 
známost jako Teaching Scotland's future (Budoucnost skotského učitelství) a později se stala vưdčím národním programovým dokumentem pro zlepšení odborného učitelského vzdělávání. Pokud jsme dříve zmiňovali přímočarost celého vývoje, je na místě připomenout, že Donaldson zpracoval svůj text na žádost ministra školství, aby bylo přezkoumáno kontinuum profesního vzdělávání učitelů ve Skotsku, počínaje výběrem uchazečů, přes počáteční (pregraduální) vzdělávání, vzdělávání v průběhu rané kariéry, až do fáze dalšího profesního rozvoje a vzdělávání vedoucích školských pracovníků.

V průběhu dalšího výkladu si budeme všímat, jak pružně a rychle dokázaly zúčastněné strany jednat. Donaldson ${ }^{4}$, který předtím působil jako ústřední inspektor HMle (Her Majesty's Inspectorate of Education - Inspektorát vzdělávání Jejího Veličenstva), obdržel zakázku v listopadu 2009 a již v únoru 2010 zahájila jeho pracovní skupina ${ }^{5}$ činnost. Společně se svými spolupracovníky navštívil Donaldson každou z univerzit poskytující vzdělávání učitelů ve Skotsku, výběr místních samospráv a škol, jednal s širokým spektrem zainteresovaných subjektů a osob. Zadal zpracování přehledové studie odborné literatury, aby shromáždil evidenci o vzdělávání učitelů ve vyspělých zemích světa - tam, kde byla identifikována inspirativní zkušenost, vedl konzultace s místími odborníky. Obdobně vyzval domácí instituce, aby poskytly príklady dobré praxe (call for evidence) a získal přes 100 plnohodnotných odpovědí. Dále administroval dotazník pro učitele $v$ činné službě s návratností od 2500 respondentů. ${ }^{6}$ Analýzy v Donaldsonově zprávě tak mají velmi široký záběr a jsou ukotveny $v$ rozsáhlé datové základně.

Výsledkem tohoto šetření a práce Donaldsonova týmu byla stostránková studie, která obsahuje pět ústředních, axiomatických myšlenek, jež jsou základem pro celkem 50 konkrétních doporučení. Hlavní myšlenky (major ideas):

- Dva nejdůležitější a současně nejdosažitelnější zpưsoby, jak může školní vzdělání naplnit vysoké aspirace, které Skotsko klade na svou mladou generaci (srov. Smart Scotland), spočívají v podpoře a posílení - zaprvé - kvality výuky a - za druhé kvality vedení škol.

- Učitelství by mělo být uznáno ve své komplexnosti a náročnosti vyžadující nejvyšší úroveň profesní způsobilosti a osobního nasazení.

- Pedagogické vedení (leadership) je založeno na principiálních hodnotách a způsobech myšlení, kterých je potřeba dosáhnout a uchovat si je již na vstupu do učitelské profese.

- Apely (imperatives), na jejichž základě bylo zformulováno Curriculum for excellence, nepozbyly na významu a budoucnost prosperujícího Skotska závisí do značné míry na realizaci jeho potenciálu. Tato skutečnost má hluboké a dosud ne zcela dořešené dopady na učitelskou profesi a její vedení.

a jak současný systém vzdělávání učitelů vybavuje učitele v průběhu jejich profesní kariéry schopnostmi reagovat na změny edukačních obsahů a uspokojovat potřeby žáků $v 21$. století.

4 Dostupné z http://www.graham-donaldson.com/.

$5 \vee V$ týmu dr. Donaldsona byli zastoupeni především představitelé školského terénu - učitelé s různou délkou praxe (včetně začínajícího učitele), ředitelé škol, vysokoškolský učitel, zástupci místní samosprávy a skotské exekutivy (srov. Donaldson, 2010, s. 113).

6 Dostupné z http://www.scotland.gov.uk/Resource/Doc/920/0120753.pdf. 
92 - Celoživotní vzdělávání učitelů, jež je v současnosti př́liš roztříštěné a často náhodné, by mělo být jádrem tohoto procesu, se všemi filozofofickými aspekty, důsledky pro kvalitu, soudržnost a efektivitu. (Donaldson, 2011, s. 2)

Pro potřeby tohoto příspěvku nás bude zajímat zejména doporučení č. 35 , které vyzývalo $\mathrm{k}$ revizi tehdejších profesních standardů pro učitele. Bylo především poukazováno na to, že jednotlivé Standardy pro různé skupiny učitelů vznikaly izolovaně od ostatních a $v$ různých obdobích, a tedy je nutné všechny dokumenty systémově propojit do jednoho celku, který bude současně reflektovat aktuální společenské potřeby: „Profesní standardy musejí být revidovány tak, aby byl vytvořen jednotný zastřešující rámec, doplněný o názorné př́ílady. Tento celkový rámec by měl odrážet rekonceptualizovaný model profesionality učitelư“ (Donaldson, 2011, s. 98).

V prosinci 2013, tedy za 10 měsíců od zahájení práce, předložili Donaldson a jeho tým dokončenou Zprávu skotské vládě. Odpověd' tajemníka Kabinetu pro vzdělávání a celoživotní učení (Cabinet secretary for education and lifelong learning) Michaela Russella byla zformulována $v$ dokumentu Pokračování v budování excelence vyučování - Odpověd' skotské vlády na program Budoucnost skotského učitelství (Continuing to build excellence in teaching - Scottih government's response to Teaching Scotland's future) již v březnu 2011. V Russelově úvodním prohlášení je patrný patos, ale současně zainteresovanost vlády na urychleném uvedení Donaldsonových doporučení do praxe:

Jednoduše řečeno, nemůžeme si dovolit, abychom se nechopili př́ležitostí pojmenovaných v Teaching Scotland's future a neposkytovali nejlepší podmínky, ve kterých se naši učitelé mohou učit a rozvíjet se a nasazovat své posílené schopnosti pro dosažení ještě vyšší úrovně vzdělávání. Současná a budoucí generace skotských dětí od nás neočekává nic menšího. (Continuing..., 2011, s. 3)

$\mathrm{Na}$ jiném místě je zdůrazněna potřeba skutečně cílevědomé akce:

Úsilí, kterého je třeba, musí být skutečně kolektivní - důsledky jsou dalekosáhlé a změna se nemůže stát přes noc. Všichni kdo jsou zaangažováni do poskytování školního vzdělávání ( $v$ místních samosprávách a ve školách samotných), do učitelské připravy a jejich dalšího vzdělávání (na univerzitách a $v$ jiných organizací) a do podpory učitelů na národní úrovni, musí být plně zapojeni. (Continuing..., 2011, s. 3)

Za tímto velkolepým účelem skotská vláda sdružila všechny zainteresované partnery z místních samosprávných orgánů, z vysokých škol, přislušných národních institucí a individuálních odborníků do Národní skupiny partnerů pro Budoucnost skotského učitelství (National partnership group for Teaching Scotland's future - NPG), $\mathrm{s}$ jasně zadaným úkolem vytvořit nové a posílené partnerství zapojené do podpory poskytování efektivního vzdělávání učitelů a jejich profesního rozvoje v každé škole ve Skotsku: „Tuto skupinu ustanovíme okamžitě a vzhledem k rozsahu práce, který se bude muset řešit, budeme požadovat, aby jako jeden z prvních výstupů předložila do konce léta plán práce a lhůty pro dosažení jednotlivých cílů.“ (tamtéž) 
Padesát původních Donaldsonových doporučení bylo přestrukturováno do šesti skupin:

1. Nastavení vzdělávací politiky a strategických směrů pro vzdělávání učitelů ve Skotsku.

2. Větší dostupnost dalšího vzdělávání učitelů prostřednictvím posílené partnerské spolupráce.

3. Získávání správných lidí pro učitelství zlepšením způsobu výběru.

4. Nejlepší start: zlepšit náš přístup v počáteční fázi vzdělávání učitelů.

5. Podpora kultury trvalého profesního vzdělávání v průběhu učitelské kariéry.

6. Podpora rozvoje nejlepšího způsobu vedení ve skotském vzdělávání.

V rámci každé z těchto oblastí vláda stanovila širší způsob řešení a formulovala klíčové kroky, které je třeba podniknout v krátkodobém i dlouhodobém horizontu.

V listopadu 2012 tedy byla ustanovena Národní skupina partnerů, jejíž členové se sešli, aby vypracovali plány k uvedení všech doporučení obsažených $v$ Teaching Scotland's future do praxe. 18. srpna 2012, v odpověd' na požadavek Kabinetu, NPG postoupila Ministerstvu taktický plán pokrývající celé spektrum problematiky od počátečního vzdělávání učitelů, až po otázky vzdělávacího leadershipu. Skupina stanovila 20 záměrů, nad jejichž prováděním převzala kontrolu nově zřízená Národní implementační rada (National implementation board). Graham Donaldson působí jako poradce této Rady.

Není bez zajímavosti podívat se, jak bylo původních padesát doporučení operacionalizováno. Především bylo opětovně deklarováno, že učitelé jsou profesionálové, od nichž se očekává dovést žáky k nejlepším možným výsledkům učení. Jako profesionálové mají smluvní nárok na trvalý profesní rozvoj (continuing professional development - CPD). Jejich zaměstnavatelé (místní samosprávy) mají za povinnost poskytovat učitelům odpovídající čas a náležitý př́istup k široké nabídce CPD. Současně se očekává, že samotní učitelé budou mít zájem reflektovat svoji práci a své zkušenosti a v dialogu se svými nadřízenými (line managers - viz dále) budou schopni identifikovat oblasti pro svůj další profesní rozvoj a zároveň nacházet příležitosti k učení a tím uplatňovat nové dovednosti a znalosti v pedagogické praxi. Tento postoj by měl být jádrem učitelské profesionality a na něj by se měla soustředit převážná pozornost, spíše než nadále precizovat vstupní požadavky na uchazeče o učitelství a neustále rozšiřovat seznam oblastí, které mají být pokryty $v$ rámci počátečního vzdělávání učitelů v pregraduální přípravě. Zdůrazněním závazku k celoživotnímu profesnímu rozvoji učitelů pomůže pozdvihnout a udržet vysoce kompetentní a angažovaný učitelský stav. Vizí skotského učitele je „praktik-expert“ zodpovědný za svůj rozvoj:

Učitelé budou aktivními partnery při rozvoji a rozšiřování své profesní praxe prostřednictvím zlepšeného modelu profesního vzdělávání. Budou zapojeni do obnoveného procesu PRD7 . Jako odborníci-badatelé (enquiring professionals) budou mít príležitosti

7 Tzv. Professional review and development (PRD) - je nárokem a současně odpovědností všech učitelů a vedoucích pracovníků jako součást jejich závazku k trvalému profesnímu učení. Zahrnuje plánování a realizaci dalšího vzdělávání učitele a jeho hodnocení založené na důkazech. 
vykonávat svou práci na mistrovské úrovni a stát se rádci svých kolegů. Budou spolupracovat s odborníky napříč vzděláváním i mimo něj a učit se od nich. (NPG, 2012, s. 24)

Požadavek trvalého sebevzdělávání všech učitelů po celou dobu profesní dráhy, bez ohledu na to, zda se jedná o čerstvé absolventy či učitele $s$ mnohaletou praxí, našel svou artikulaci např́ič skotskými profesními standardy učitelství a byl akcentován zavedením nového on-line evaluačního systému Professional update (PU) pro administraci individuálního rozvoje každého učitele; obojí pod supervizí GTCS. V systému PU jsou učitelé od srpna 2014 povinni aktualizovat své údaje v Registru a uvádět údaje o svých dovednostech a znalostech nabytých během samostudia a dalšího vzdělávání ve škole a mimo ni (kurzy, stáže, stínování apod.). $K$ tomu mají využívat (sebe)hodnocení podle profesního standardu, doklady (např. certifikáty) o vzdělávání, či hodnocení jejich nadřizenými a aktualizovat tyto informace každých pět let, včetně potvrzení nadřízeného pracovníka o jejich setrvalém angažmá v profesním rozvoji.

To odkazuje k ústřední roli GTCS při zajištování infrastruktury v procesu implementace řady změn $v$ systému. Klíčovým předpokladem obecně je partnerství. Partnerství mezi institucemi a organizacemi poskytujícími vzdělávací př́ležitosti, ovšem také mezi univerzitami, místními samosprávami a samotnými učiteli jako aktivními účastníky vlastního rozvoje a jejich profesními sdruženími. V př́padě Standardů se jedná konkrétně o podpůrnou skupinu Standards support group, která sdružuje kandidáty z každé profesní asociace učitelů ve Skotsku (viz The association of chartered teachers in Scotland a další).

\section{Skotští učitelé a standard}

Ve Skotsku ve školním roce 2013/14 působí 75000 učitelů. Všichni aktivní skotští učitelé musejí být zapsání v Registru ${ }^{8}$, který spravuje GTCS. Registrace je podmínkou, aby mohl být učitel zaměstnán orgánem místní samosprávy na veřejné mateřské, základní, střední nebo speciální škole, a do Registru jsou zapsáni pouze učitelé s odpovídající učitelskou kvalifikací (Teaching qualification - TQ). Učitelé primárního a sekundárního stupně získávají kvalifikaci čtyřletým studiem vedoucím $\mathrm{k}$ získání bakalářského titulu B.Ed. na jedné z devíti skotských univerzit poskytujících přípravné vzdělávání učitelů. Toto studium zahrnuje minimálně 30 týdnů praxe ve školách. Ti, kteří již mají vysokoškolské vzdělání a chtějí působit jako učitelé, absolvují jednoroční kurz (včetně min. 18 týdnů pedagogické praxe) a dosáhnou vysokoškolského titulu Professional graduate diploma in education - PGDE pro primární nebo sekundární stupeň. Skotské ministerstvo školství prostřednictví svého Direktorátu pro

Celý proces probíhá v prostředí podpưrné, kolegiální kultury a profesionálního dialogu učitele a jeho prímého nadřízeného (line manager). PRD požaduje pravidelná setkávání učitele a jeho liniového manažera a vést o těchto pohovorech záznamy.

8 Vytvořením analogického registru v České republice se zabývá MŠMT ČR, viz http://zpravy.idnes .cz/vznikne-registr-ucitelu-087-/domaci.aspx?c=A140315_105954_domaci_jj. 
učení (Scottish government learning directorate - SGLD) dohlíží na kvalitu učitelské přípravy, včetně stanovování minimálních vstupních požadavků pro přijetí uchazečů k učitelskému studiu (Memorandum on entry requirements to programmes of initial teacher education in Scotland; GTCS, 2013).

General teaching council, ve spolupráci se skotskou vládou, definuje Standard pro přechodnou registraci (The standard for provisional registration; GTCS, 2013), který stanoví očekávané kompetence budoucích učitelů na konci jejich univerzitního studia. Studenti učitelství, kteři dosáhli učitelskou kvalifikaci (TQ), jsou dočasně vedeni v Registru GTSC jako tzv. probationer teachers. Plná registrace následuje po absolvování zkušební doby v délce 1 školního roku (period of probation), na jejímž konci je učitel posuzován, zda dosáhl Standardu pro plnou registraci (The standard for full registration; GTCS, 2013).

Skotské standardy jsou proklamovány jako významný nástroj profesního rưstu učitelů9. Kariérní model poskytuje perspektivy jednak těm učitelům, kteři dávají přednost práci ve třídě, jednak učitelům aspirujícím podílet se na řízení školy a přebírat manažerské odpovědnosti. Kariérní postup prvně jmenovaných vede od plně registrovaného učitele k získání statusu diplomovaný učitel (chartered teacher). Učitelé, kteři se chtějí připravovat pro tuto prričku, musí prokázat závazek k trvalému profesnímu rozvoji. Status Chartered teacher vyžaduje splnění Standardu pro profesní učení v průběhu kariéry (The standard for career-long professional learning), a to bud' úspěšným absolvováním modulárních kurzů, jejichž cílem je zlepšovat praxi ve třídě, nebo předložením portfolia prokazujícím dosavadní profesní učení. Směřování k postu zástupce ředitele a ředitele školy zakládá přihláška učitele na inzerovanou vedoucí pozici, přičemž se vyžaduje, aby žadatelé prokázali naplňování Standardu pro vedoucí pracovníky (The standards for leadership and management), a to prostřednictvím Skotské kvalifikace pro vedoucí pracovníky (Scottish qualification for headship) nebo se vykázali ekvivalentní zkušeností a dovednostmi.

Na podporu vysoké informovanosti učitelů o standardech spravuje GTCS webové stránky (www.gtcs.org.uk), na kterých jsou snadno k dohledání veškeré dokumenty, doplňující informace a instrukce, motivační a vysvětlující videa a rovněž praktický Instrumentář pro vlastní hodnocení (A toolkit for self evaluation). Sebehodnocení podle Standardů je nedílnou součástí profesního rozvoje zakotvené v systému Professional update (viz výše). Instrumentář operacionalizuje jednotlivé oficiální formulace Standardu do konkrétních výroků v jazyce „Já rozumím..., já dokážu...,“ takže učitelům usnadňuje v úplnosti porozumět všem očekáváním, která jsou na ně kladena, a identifikovat, jak daleko jsou na cestě k naplnění toho kterého kritéria. Interaktivně pracovat s tímto svým sebehodnocením mohou učitelé v prostředí MyGTSC, v němž si mohou vytisknout přehled jako základ pro diskusi se svým nadřize-

9 Namístě je jistá opatrnost. Např. badatelé McNally a Blake z University of Strathclyde realizovali 370 polostrukturovaných interview se 133 učiteli v prvním roce jejich učitelské kariéry, avšak jen jedenkrát z celého výzkumného vzorku zazněla kladná zmínka o Standardu pro plnou registraci jako nástroji rozvoje. „Výsledky odhalily zarážející kontrast mezi zkušenostmi začínajících učitelů ve školách a jejich rozvojem prostřednictvím profesních standardů.“ (2012, s. 198) 
96 ným v pravidelném výročním hodnotícím pohovoru v rámci PRD (Professional review and development).

Paralelně k systému standardů ve Skotsku je učitelská profese vymezena prostřednictvím Profesního kodexu (Code of professionalism and conduct - CoPAC; GTCS, 2012d). Tento normativní dokument stanovuje základní profesní principy a hodnoty závazné pro registrované učitele. Obdobný soubor norem existuje i pro studenty učitelství (The student teacher code; GTSC, 2012e). Kodex pochopitelně nemůže řešit všechny možné profesní situace, $v$ nichž se mohou učitelé ocitnout. Nicméně se předpokládá, že by učitelé měli v duchu Kodexu korigovat veškeré své počínání jak ve třídě, tak mimo ni. Je důležité připomenout, že Kodex je adresován nejen učitelům samotným, ale vztahuje se i na představitele veřejné správy, které rovněž zavazuje k normám chování a ke kompetencím vyžadovaných od registrovaných učitelů. Ačkoli se jednání popsané v Kodexu mưže jevit většině čtenářư jako naprosto samozřejmé, jednoznačné vymezení hranic profesionálního chování a jednání je prvotním předpokladem důvěryhodnosti učitelů v očích široké veřejnosti.

\section{Profesní standardy učitelství ve Skotsku}

Nové, revidované profesní standardy začaly ve Skotsku platit od srpna 2013. Není $v$ možnostech tohoto př́spěvku do detailu komparovat tyto nové Standardy s jejich dřivější podobou z roku 2009, resp. 2005 či 2002. Upozorníme pouze na jeden vybraný moment, který autor tohoto textu považuje za nejvýznamnější, a to je položení primárního důrazu na profesní hodnoty.

Vezměme pro př́klad Standard pro diplomované učitele (The standard for charterd teachers) ve verzi z roku 2002 (Scottish executive, 2002) a 2009 (Scottish government, 2009) a navazující Standard profesního učení v průběhu kariéry (The standard for career-long professional learning; GTCS, 2012b), který nahradil předchozí dva jmenované v roce 2013. Abychom ilustrovali zřejmou strukturální kontinuitu, můžeme poukázat, že tyto tři dokumenty sestávají z týchž čtyř klíčových komponentů (components; srov. príloha 1): (1) profesní hodnoty a osobní angažovanost, (2) profesní znalosti a porozumění, (3) profesionální a osobnostní vlastnosti (2002), resp. profesní dovednosti a schopnosti $(2009,2013)$ a (4) profesionální jednání. Při revizi Standardů v roce 2013 dochází k principiálnímu posunu, který je dobře patrný z grafického modelu Standardů (viz přiloha 1). Až dosud bylo „profesionální jednání“ zobrazováno jako středobod Standardů, jakýsi vrchol pyramidy či výslednice vzájemně provázaných komponentů Standardu, hlavní výstup. To je zřejmé z následujícího komentáře:

Tyto čtyři komponenty jsou všechny považovány za klíčové a vzájemně se podmiňující. Nicméně, například význam silného osobního angažmá nebo schopnost argumentovat své jednání jsou limitovány, pokud nevedou k efektivnímu jednání; obdobně ovládnutí př́slušných znalostí má omezenou hodnotu, pokud takové znalosti nejsou vhodně zužitkovány k podpoře učení. (Scottish government, 2009, s. 3) 
V dokumentu z roku 2013 je zřejmý primární důraz na profesní hodnoty učitele:

Profesní hodnoty jsou v srdci Profesních standardů. Edukační zkušenosti všech našich studentů jsou utvářeny prostřednictvím hodnot a postojů všech těch, kteří se na jejich vzdělávání podílejí. Hodnoty jsou komplexní a představují ideály, které určují profesionalitu našeho jednání. (...) Jsou nedílnou součástí veškeré naší profesní praxe a všeho, co děláme, abychom splnili své profesionální závazky a povinnosti jako učitelé registrovaní GTCS. (GTCS, 2012b, s. 6)

Je tedy zřejmé, že nové pojetí Standardů usiluje postihnout samé jádro učitelovy profesionality tím, že se soustředí na morální a etickou dimenzi učitelství (srov. Korthagen, 2004; Píšová, 2011, s. 18), nikoli především na vnější, pozorovatelné jednání. Otázkám profesních hodnot jako principiálního východiska Standardů se ještě budeme věnovat níže. Vzhledem $k$ omezenému prostoru se nyní plně zaměříme na stávající uspořádání a obsah Standardů.

Jak už bylo řečeno, skotské standardy jsou strukturovány do tří základních dokumentů (viz obr. 1):

1. Standard pro registraci (The standards for registration: mandatory requirements for registration with the General teaching council for Scotland; GTCS, 2012a). Tato skupina standardů obsahuje ve společném dokumentu zvlášt' vymezený Standard pro dočasnou registraci (The standard for provisional registration - SPR) a Standard pro plnou registraci (The standard for full registration - SFR).

2. Standard profesního učení v průběhu kariéry (The standard for career-long professional learning: supporting the development of teacher professional learning SCLPL; GTCS, 2012b).

3. Standard pro vedoucí pracovníky (The standards for leadership and management: supporting leadership and management development; GTCS, 2012c), který ve společném dokumentu definuje Standard pro střední management (The standard for middle leadership - SLM-ML) a Standard pro ředitele (The standard for headship - SLM-HT).

Soubor Standardů je používán v řadě oblastí a $\mathrm{k}$ mnoha účelům, např.: ${ }^{10}$

- jako kritérium pro vstup do učitelské profese,

- jako měřítko (benchmark) kompetence učitelů (s výjimkou Standardu pro vedoucí pracovníky),

- jako kontinuum pro učení a profesní rozvoj během celé profesní kariéry,

- jako rámec sebehodnocení a reflexe,

- pro tvorbu a hodnocení vzdělávacích programů pro učitele a jejich akreditaci,

- při náboru učitelů a výběrových řizeních,

- na podporu trvalé diskuse o úkolech učitelů a jejich profesionalitě,

- jako podklad pro systémy Professional review and development (PRD) a Professional update $(\mathrm{PU})$ a další.

10 Dostupné z: http://www.gtcs.org.uk/standards/about-the-standards.aspx. 


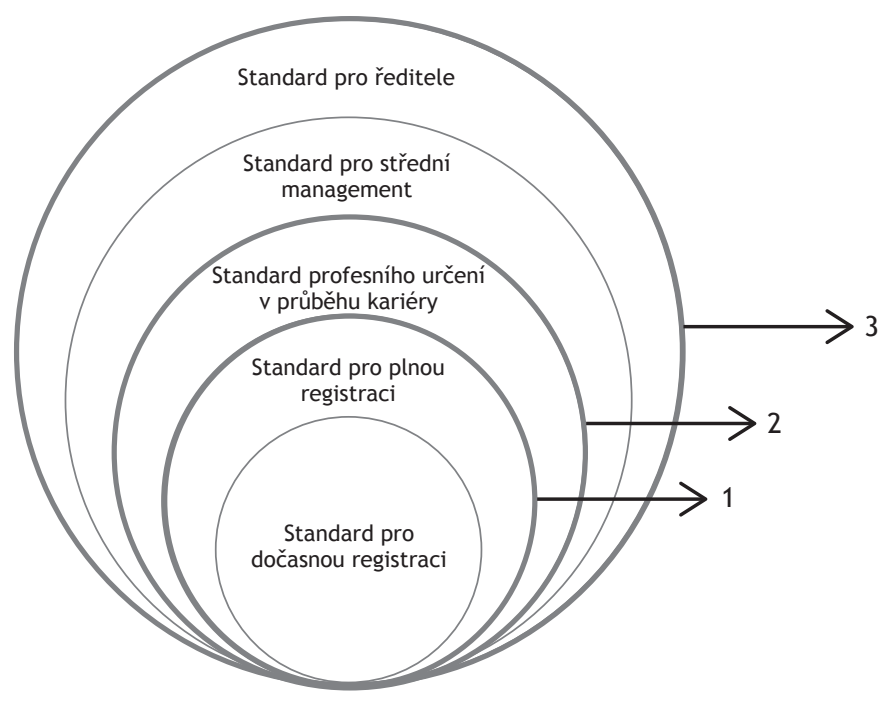

Obrázek 1 Systém profesních standardů učitelství ve Skotsku je popsán ve třech samostatných dokumentech, které stanovují pět úrovní. Upraveno podle GTCS (2012a).

Napřičc celým souborem Standardů jde několik klíčových principů (GTCS, 2012a):

Profesní hodnoty a osobní závazek: demokratické hodnoty jsou jádrem skotské společnosti, a proto i profesní hodnoty a osobní závazek, který na sebe učitel jako profesionál bere, jsou v srdci Standardů. Poprvé jsou ty stejné hodnoty vtěleny do Standardů všech úrovní jako manifest společného profesního východiska učitelů bez ohledu na délku praxe a postavení v hierarchii.

Učení pro udržitelnost: představuje závazek, který podněcuje školu i její širší komunitu rozvíjet takové znalosti, dovednosti, postoje, hodnoty a jednání, které jsou nezbytné pro odpovědné rozhodování v souladu s konceptem udržitelné budoucnosti a spravedlivého světa. Profesionalita učitelů má stát na aktivním postoji k problémům společnosti na lokální i globální úrovni a očekává se, že budou uplatňovat zásady udržitelnosti ve všech oblastech své práce. Předním úkolem učitelů je tak podporovat žáky, aby vyrůstali v odpovědné občany podílejícími se na rovné a spravedlivé společnosti.

Leadership: Všichni učitelé mají příležitost jednat jako lídři. Východiskem je vedení svěřených žáků, ale rovněž podíl na podpoře rozvoje svých kolegů, budování vztahů kolegiality a profesní synergie.

Jednotlivé prvky (elements) všech Standardů jsou organizovány do vzájemně propojených kategorií, kdy Profesní hodnoty (Professional values) a Osobní závazek (Personal commitment) jsou v samém středu cibulového modelu. Žádný článek nestojí sám o sobě, všechny jsou neodmyslitelně provázány a v tomto rámci je komplexně rozvíjena profesionalita učitelů (srov. obr. 2). 


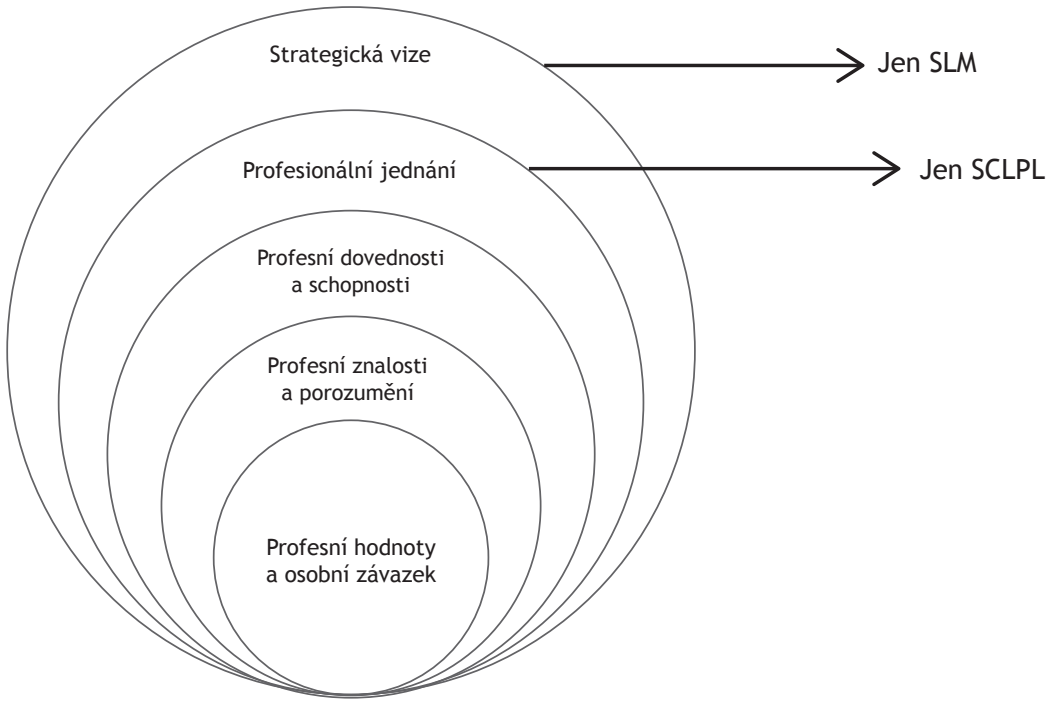

Obrázek 2 Model uspořádání vzájemně propojených prvků Standardu. Upraveno podle GTCS (2012c).

Podívejme se nyní, jak jsou ve Skotsku vymezeny Profesní hodnoty a osobní závazek učitelů. Ty představují výchozí profesionální odpovědnost všech učitelů registrovaných ve Skotsku k péči o duševní, etický a sociální růst a blahobyt žáků, nebot' edukační zkušenosti žáků jsou utvářeny skrze hodnoty a dispozice těch, kteří je vzdělávají, tedy učitelů. Profesionalita učitelů také znamená klást si zásadní školskopolitické otázky a porovnávat s nimi své postoje a názory. Dalším důležitým předpokladem je, aby učitelé ve své každodenní práci opakovaně své hodnoty reflektovali a přezkoumávali, zda stále odpovídají potřebám vyvíjející se společnosti a potřebám žáků. Profesní hodnoty a osobní postoje jádrové pro učitelskou profesi jsou (GTCS, 2012a, s. 5-6):

\section{Sociální spravedlnost}

- Přijetí (na lokální i globální úrovni) vzdělávací a sociální hodnoty udržitelnosti, rovnosti a spravedlnosti a uznání práv a odpovědnosti současné i budoucí generace.

- Závazek k zásadám demokracie a sociální spravedlnosti ve vztahu k věku, zdravotnímu postižení, pohlaví a genderové identitě, rase, etnickému původu, náboženství a víre a sexuální orientaci.

- Oceňování a respektování sociální, kulturní a ekologické rozmanitosti.

- Závazek k zapojování studentů do reálných problémů, rozšiřování jejich vzdělávacích zkušeností, zvyšování výsledků a k podpoře učení jako cesty k lepší budoucnosti.

- Respektování práv všech žáků, jak je uvedeno v Úmluvě Organizace spojených národů o právech dítěte. 
Integrita

- Otevřenost, upřímnost, odvaha a moudrost.

- Kritické zkoumání osobních a profesních postojů, přesvědčení, předpokladů a profesní praxe.

- Kritická reflexe provázanosti osobních a profesních postojů a přesvědčení, hodnot a postupů za účelem zlepšování. Pokud je to žádoucí, činí změny v praxi.

\section{Dưvěra a respekt}

- Jednat a chovat se způsobem, který rozvíjí klima důvěry a respektu.

- Poskytování a zajišt’ování bezpečného prostředí pro všechny žáky; pečující, chápající a soucitný étos.

- Převzetí závazku motivovat a inspirovat žáky. Uznává jejich sociální a ekonomický kontext, individualitu a specifické vzdělávací potřeby a bere ohled na překážky v učení.

\section{Profesní závazek (Professional commitment)}

- Pracovní kolegialita a zapojení se všemi aspekty odborné praxe do spolupráce se všemi členy vzdělávacích komunit s nadšením, přizpůsobivostí a konstruktivní kritičností.

- Závazek k celoživotnímu učení a profesnímu rozvoji jako hlavním aspektům profesionality. (GTCS, 2012a, s. 5-6)

V navazujícím textu ve stručnosti představíme specifické obsahy jednotlivých Standardů, přičemž podáme pouze př́kladové ukázky (viz tabulka 1-5), aby byla patrná jazyková a obsahová forma a dikce Standardů. Kompletní přehled, předpokládáme, získá čtenář z originálního textu dostupného na webových stránkách GTCS.

\subsection{Standard pro registraci}

Standard pro dočasnou registraci (The standard for provisional registration - SPR), jak již víme, určuje, co se očekává od studenta učitelství na konci jeho vysokoškolské př́pravy (initial teacher education). Poté, co student získá SPR a s ní dočasný zápis do Registru GTCS, pokračuje na své profesní dráze k dosažení Standardu pro plnou registraci (The standard for full registration - SFR). SFR je vstupní bránou do učitelské profese a je měřítkem (benchmark) učitelské kompetence pro všechny učitele. SFR tedy popisuje žádoucí úroveň způsobilosti v pedagogickém výkonu, která je zárukou kvality učitelovy práce ve vztahu žákům, rodičům, kolegům i širší komunitě.

Z druhé strany není záměrem, aby se se Standardem pracovalo jako s kontrolním seznamem bod po bodu. Spíše jde o to, aby osoba, která hodnotí práci učitele podle Standaru, nabyla jistoty, že učitel obecně disponuje způsobilostmi, které jsou zde popsány. V případech, kdy je namístě potřeba určitého zlepšení, poskytuje výčet Profesionálního jednání (viz níže) přehled oblastí, na které se lze zaměřit. Avšak i poté, co učitel dosáhl SFR, očekává se, že bude nadále rozvíjet své znalosti a zku- 
šenosti ve všech oblastech odborné praxe prostřednictvím odpovídajícího a trvalého profesního vzdělávání.

Dokument obsahuje na prvním místě vymezení Profesních hodnot a osobního závazku (viz výše) a dále jsou tabelovány vždy ve dvou sloupcích (SPR/SFR) oblasti Profesní znalosti a porozumění a Profesionální dovednosti a schopnosti. Tyto oblasti jsou vnitřně dále strukturovány (viz niže) s uvedením Profesionálního jednání, v celkovém rozsahu 19 stran dokumentu:

\section{Profesní znalosti a porozumění}

1. Kurikulum

- Zná a chápe podstatu kurikula a jeho rozvíjení.

- Zná a chápe podstatu odpovídající oblasti předškolního, primárního a sekundárního kurikula.

2. Vzdělávací systém a profesní odpovědnost

- Zná a chápe podstatné znaky vzdělávacího systému, vzdělávací politiky a praxe.

- Zná a chápe principy hodnocení, dokumentování a reportování.

- Rozumí školním a učebním komunitám, v nichž vyučuje, a své vlastní odpovědnosti vưči nim.

3. Pedagogická teorie a praxe

- Zná a chápe relevantní vzdělávací principy a pedagogické teorie ve vztahu k praxi.

- Rozumí důležitosti výzkumu a zapojení do profesního bádání.

Tabulka 1 Př́kladový deskriptor profesních znalostí a porozumění na úrovni SPR/SFR

\begin{tabular}{ll}
\hline Standard pro dočasnou registraci & Standard pro plnou registraci \\
\hline Disponuje znalostmi a porozuměním podstatě kurikula a jeho rozvíjení \\
\hline Profesionální jednání & Profesionální jednání: \\
Student učitelství: & Registrovaný učitel: \\
- rozvíjí své porozumění principům tvorby & • bezpečně a detailně rozumí principům \\
kurikula a kontextu učení; & tvorby kurikula a dovode je uplatnit ve všech \\
- zná procesy změny a rozvoje kurikula & podmínkách, v nichž dochází k učení; \\
a rozumí jim; & • bezpečně zná a do detailu chápe procesy \\
- buduje si povědomí o propojenosti různých & změny a rozvoje kurikula; \\
kurikulárních oblastí, etap a odvětví. & • ví, jak určit a zdůraznit souvislosti např́č \\
& rưznými kurikulárními oblastmi, etapami \\
& a odvětvími, podporuje učení za hranicemi \\
& jednotlivých předmětů. (GTCS, 2012a, s. 7) \\
\hline
\end{tabular}

\section{Profesní dovednosti a schopnosti}

1. Vyučování a učení

- Plánuje promyšlené, rozvíjející a podnětné učební programy, které odpovídají potřebám a schopnostem žáků.

- Efektivně komunikuje a produktivně jedná se žáky, individuálně i kolektivně. 
- Uplatňuje široké spektrum vyučovacích strategií a výukových zdrojů odpovídajících potřebám a schopnostem žáků.

- Klade na žáky vysoká očekávání.

- Vytváří atmosféru spolupráce při podpoře učení a pocitu pohody.

2. Organizace a řizení tř́dy

- Vytváří bezpečné, pečující a smysluplné učební prostředí.

- Buduje pozitivní vztahy a uplatňuje pozitivní výchovné př́stupy.

3. Hodnocení žáků

- Použivá hodnocení, evidenci a reportování jako nedílnou součást učebního procesu $\mathrm{k}$ podpoře a posílení učení.

4. Profesní reflexe a komunikace

- Čte a kriticky se zabývá odbornou literaturou, pedagogickým výzkumem a vzdělávací politikou.

- Angažuje se $v$ reflektivní praxi za účelem rozvoje a zvyšování trvalého profesního učení a expertnosti.

Tabulka 2 Příkladový deskriptor profesních dovedností a schopností na úrovni SPR/SFR

\begin{tabular}{|c|c|}
\hline Standard pro dočasnou registraci & Standard pro plnou registraci \\
\hline \multicolumn{2}{|c|}{$\begin{array}{l}\text { Plánuje promyšlené, rozvíjející a podnětné učební programy, které odpovídají potřebám } \\
\text { a schopnostem žáků. }\end{array}$} \\
\hline $\begin{array}{l}\text { Profesionální jednání } \\
\text { Student učitelství: } \\
\text { - vhodným způsobem plánuje efektivní výuku } \\
\text { za účelem uspokojení vzdělávacích potřeb } \\
\text { všech žáků, včetně čtenářské a matematické } \\
\text { gramotnosti, zdraví a psychické pohody } \\
\text { a dovedností pro učení, život a práci. }\end{array}$ & $\begin{array}{l}\text { Profesionální jednání: } \\
\text { Registrovaný učitel: } \\
\text { - vhodným způsobem, v různých kontextech } \\
\text { a časových horizontech, plánuje efektivní } \\
\text { vyučování a učení, aby naplňovalo potřeby } \\
\text { všech žáků, včetně čtenářské a matematické } \\
\text { gramotnosti, zdraví a psychické pohody } \\
\text { a dovedností pro učení, život a práci. } \\
\text { (GTCS, 2012a, s. 13) }\end{array}$ \\
\hline
\end{tabular}

\subsection{Standard pro profesní učení v průběhu kariéry}

Tento Standard nahradil dřivější normu z roku 2009 (The standard for chartered teacher). Je členěn do tř́i oddílů s celkovým rozsahem 10 stran.

\section{Profesní hodnoty a osobní závazek (viz výše)}

Profesní znalosti a porozumění: Od učitelů pracujících s tímto Standardem se očekává, že budou do hloubky rozvíjet a kriticky propracovávat své znalosti a porozumění za účelem posílení svých schopností a dovedností v klíčových oblastech jejich celoživotní profesní dráhy:

1. pedagogika, učení a znalost vyučovaného oboru;

2. kurikulum a hodnocení; 
3. sledování nových informací (enquiry) a výzkum;

4. vzdělávací kontext a aktuální debata v politice, ve vzdělávání a v praxi;

5. udržování a rozvíjení profesního učení;

6. učení pro udržitelnost.

Od učitelů se dále očekává, že budou rozvíjet a uplatňovat své znalosti, dovednosti a expertnost prostřednictvím sledování nových informací a trvalého profesního učení za těmito účely:

- prohlubovat a rozvíjet oborové, kurikulární, a pedagogické znalosti, aby byl učitel schopen vést své žáky a učení svých kolegů;

- klást otázky, rozvíjet a projasňovat problémy praxe kriticky poučeným způsobem a nabízet kvalifikovaná zdůvodnění pro své profesionální jednání;

- systematicky prozkoumávat, analyzovat a evaluovat účinky praxe;

- kriticky přezkoumávat a zpochybňovat předpoklady, předsvědčení a hodnoty své vlastní i v rámci celého systému;

- kriticky studovat odbornou literaturu, sledovat výzkum a vzdělávací politiku s cílem smysluplně propojovat teorii a praxi a zavádět změny, kde je to vhodné;

- vytvářet, rozvíjet a vést kulturu kolegiality, a to prostřednictvím rozhovorů s ostatními učiteli, vzájemnými hospitacemi s konstruktivní zpětnou vazbou, zapojením do profesní debaty;

- spolupracovat napříč disciplínami, profesemi a komunitami, místně i celosvětově. (GTSC, 2012b, s. 8)

Profesní jednání v průběhu celoživotního učení: Klíčové oblasti celoživotního profesního učení se překrývají s profesními znalostmi a porozuměním, které jsme uvedli výše. Zde opět uvádíme př́kladově popis profesionálního jednání pro jednu klíčovou oblast.

Tabulka 3 Příkladový deskriptor profesionálního jednání na úrovni SCLPL

\begin{tabular}{|c|c|}
\hline Klíčová oblast & Profesionální jednání \\
\hline $\begin{array}{l}\text { Pedagogika, učení } \\
\text { a znalost vyučovaného } \\
\text { oboru }\end{array}$ & $\begin{array}{l}\text { - prokazuje hluboké znalosti svého oboru a pedagogického vedení } \\
\text { (žákú, třídy); } \\
\text { - rozvíjí kurikulum s hlubokým porozuměním smyslu předmětového } \\
\text { učiva a širšího smyslu vzdělávání; } \\
\text { - prokazuje důkladné porozumění výukovým metodám, pedagogické } \\
\text { teorii a praxi; } \\
\text { - rozvíjí konstruktivní pedagogický vztah se žáky; } \\
\text { - prokazuje důkladnou znalost digitálních technologií a jak tyto mohou } \\
\text { být využívány k podpoře učení; } \\
\text { - zná a vytváří nejvhodnější prostředí pro učení, včetně učení mimo } \\
\text { třídu, a je schopen v těchto prostředích uplatňovat odpovídající } \\
\text { postupy. (GTSC, 2012b, s. 9) }\end{array}$ \\
\hline
\end{tabular}


Tento Standard nahradil dřivější normu z roku 2005 (The standard for headship). Je určen pro sebehodnocení a profesní rozvoj těm pracovníkům, kteří ve školách zastávají formální vedoucí role, nebo na tyto pozice aspirují. Do jednoho dokumentu je zařazen Standard pro sřední management (The standard for middle leadership SLM-ML) a Standard pro ředitele (The standard for headship - SLM-HT).

Jak už jsme dřive poukázali (Voda, 2013), téma leadershipu je v rámci Standardů jedno z ústředních. Docenění významu kvality vedoucích pracovníků pro celý vzdělávací systém je dobře patrné např́klad v následujícím prohlášení:

Skotská vláda si plně uvědomuje význam pedagogického leadershipu (educational leadership) při zlepšování výsledků dětí a mládeže. Chceme povzbudit všechny učitele, aby se ujímali lídrovských rolí, a budeme nadále podporovat koncept leadershipu na všech úrovních. Chceme se posunout do té míry, kdy dosažení standardu pro vedoucí pracovníky bude povinné pro všechny ředitele škol, a budeme spolupracovat se Skotskou akademií vzdělávacího leadershipu na přiblížení se k tomuto cíli. (Michael Russell, tajemník Kabinetu pro vzdělání a celoživotní učení, GTCS, 15. 3. 2014)

Oproti výše popsaným standardům obsahuje Standard pro vedoucí pracovníky tyto specifické oblasti vázané na profesní kontext spojený s výkonem funkce:

Vize: Školský leader řídí tvorbu a sdílení vizí, étosu a cílů organizace, které inspirují a motivují žáky, učitelský sbor a všechny členy učící se komunity a její partnery. Stanovuje vysoká očekávání od každého žáka. Zásadní je závazek všech leaderů k celoživotnímu učení, schopnost stát modelem jako „vůdčí učící se“, a tak podporovat ostatní k celoživotnímu učení za účelem zlepšení jejich praxe. (GTSC, 2012c, s. 8)

Profesní znalosti a porozumění představují komplexní znalosti a chápání pedagogického myšlení a jeho vývoje potřebné pro úspěšného lídra vzdělávání. Jsou vymezeny takto:

- Vyučování a učení - leader přistupuje kriticky k poznatkům pedagogického výzkumu a spolupracuje s ostatními při aplikaci vhodného rozvojového plánu pro zlepšení výsledků žáků.

- Vzdělávací politika - leader kriticky uplatňuje své znalosti výzkumu a vývoje vzdělávací politiky $k$ podpoře rozvoje školy.

- Sociální a environmentální trendy a rozvoj - leader drží krok se změnami ve společnosti, s rozvojem digitálních technologií, s proměnou životního prostředí a globální komunity, uplatňuje a rozšiřuje své znalosti a vyvozuje důsledky pro leadership.

- Leadership and management - leader si neustále rozšiřuje své znalosti a vědomosti o konceptech rrízení a vedení v daném kontextu a spolupracuje s ostatními, aby je využil v praxi. (GTSC, 2012c, s. 8-9) 
Interpersonální dovednosti a schopnosti:

- Demonstruje sebevědomí a inspiruje a motivuje ostatní - leader neustále upevňuje své profesní sebevědomí pravidelným promýšlením své práce prostřednictvím reflexe a kritického tázání. Řídí sebe a ostatní efektivně, kolegiálně. Buduje si a upevňuje osobní důvěryhodnost tím, že je modelem celoživotního učení, bezúhonnosti, etiky, rozvíjí kulturu důvěry a respektu. Projevuje spolehlivost a odvahu při vypořádávání se s kritikou a s konflikty. Leader podporuje rozvoj vưdčích dovedností u druhých, rozvíjí důvěru a respekt mezi kolegy tím, že podporuje príležitosti k vedení ve škole i mimo školu. Povzbuzuje pozitivní budování vztahů se studenty, kolegy, rodiči a dalšími partnery.

- Dělá moudré úsudky a rozhoduje se adekvátně - leader objektivně vyhodnocuje a určuje situace. Snaží se o pozitivní řešení. Ví jak a kdy se rozhodovat na základě faktů a informací, které mu usnadňují úsudek. Je ochotný zapojit se do diskuse a prosazuje konstruktivní způsoby, jak dosáhnout zlepšení. Dává najevo etické užití moci a autority.

- Efektivně komunikuje - leader každodenně prokazuje svůj pevný závazek vưči vzdělávání a blahu žáků. Je schopný komunikátor napřič školou i širší komunitou a vytváŕí účelné vztahy. V profesionálním odborném dialogu, při poskytování konstruktivní zpětné vazby a v organizační komunikaci naslouchá a vyjadřuje srozumitelně své myšlenky a pocity. $\mathrm{K}$ tomu využívá vhodných médií a informační technologie. Je otevřený a poctivý v jednání s ostatními. Citlivě a eticky pracuje s dưvěrnými informacemi.

- Prokazuje politický vhled - leader rozumí dynamice politické moci a vlivu ve vztahu mezi školou a společností a odvozuje z toho důsledky pro činnost jeho organizace. Rozumí politickému a sociálnímu kontextu a bere ho do úvahy při rídicí práci. (GTCS, 2012c, s. 9-10)

Profesionální jednání pracovníků středního managementu, čili pracovníků na nižších stupních řízení je vymezeno pěti základními oblastmi odborné činnosti. Ve shodě s vizí a hodnotami školy spolu s ostatními střední manažer:

1. Rozvíjí škálu strategií pro individuální i kolektivní autoevaluaci, které přispívají k rozvoji školy.

2. Rozvíjí koherentní přístupy k profesnímu vzdělávání, které zakládají a udržují pedagogické jednání učitelů.

3. Pracují kooperativně na zlepšování učení, které vede k vysoké kvalitě vzdělávacích výsledků.

4. Budují a udržují partnerství s kolegy, žáky, rodiči a ostatními zainteresovanými subjekty pro naplnění identifikovaných potřeb všech žáků.

5. Proaktivně a efektivně spravuje svěřené prostředky k naplňování vzdělávacích a rozvojových priorit. 
Tabulka 4 Příkladový deskriptor profesionálního jednání na úrovni SLM-ML

\begin{tabular}{|c|c|}
\hline Profesní standard & Profesionální jednání \\
\hline $\begin{array}{l}\text { Střední manažer umožňuje } \\
\text { zaměstnancům indiviuálně } \\
\text { i kolektivně zapojovat se } \\
\text { do pravidelné a rigorózní } \\
\text { autoevaluace }\end{array}$ & $\begin{array}{l}\text { - systematicky používá zavedené autoevaluační procesy, } \\
\text { shromažd'uje informace od relevantních partnerů a využivá } \\
\text { těchto informací k plánování následných kroků a opatření; } \\
\text { - rozvíjí dovednosti a sebedůvěru svých kolegů při využívání } \\
\text { zavedených autoevaluačních procesů. (GTSC, 2012c, s. 11) }\end{array}$ \\
\hline
\end{tabular}

\section{Profesionální jednání ředitelů škol:}

1. Zakládá, udržuje a zlepšuje kulturu vlastního hodnocení školy.

2. Rozvíjí schopnosti, odbornou kapacitu učitelského sboru a leadership k podpoře učení.

3. Zajišt'uje trvale vysokou kvalitu výuky pro všechny žáky.

4. Buduje a prohlubuje partnerství se žáky, jejich rodinami a relevantními partnery k uspokojení zjištěných potřeb všech žáků.

5 Efektivně přiděluje zdroje v souladu se strategickými a provozními prioritami.

Tabulka 5 Příkladový deskriptor profesionálního jednání na úrovni SLM-HM

\begin{tabular}{ll}
\hline Profesní standard & Profesionální jednání \\
\hline Ředitel stanoví pravidla & • stojí příkladem (modelem) v osobním sebehodnocení na \\
a postupy na podporu & základě příslušného profesního standardu a vhodných kritérií; \\
vlastního hodnocení na všech & $\begin{array}{l}\text { - prosazuje otevřený, upřímný a kritický postoj vǔči hodnotícím } \\
\text { úrovních ve škole }\end{array}$ \\
& postupům; \\
& povzbuzuje a podporuje ostatní, aby kriticky analyzovali \\
& a hodnotli svoji vlastní praxi v souvislosti s př́slušnými \\
& standardy a postupy. (GTSC, 2012c, s. 17) \\
\hline
\end{tabular}

\section{Diskuse a závěr}

Charakteristickým znakem profesionalizace učitelů ve Skotsku, který autorovi tohoto textu v osobním rozhovoru shodně potvrdili pracovníci činní na různých úrovních skotského vzdělávacího systému, je kulturně podmíněná důvěra v učitele. Ti jsou očima veřejnosti hodnoceni jako plně kompetentní, angažovaní a pracovití profesionálové. Tento status učitele není jakkoli zpochybňován, naopak má svá vyjádření i v rétorice oficiálních orgánů (srov. motto v záhlaví tohoto příspěvku). Standardy ve Skotsku tedy nejsou principiálně pojímány tak, aby byly nástrojem kontroly a rozlišovaly na dobré a špatné učitele, ale výhradně za účelem identifikace rozvojových potřeb učitelů a $\mathrm{k}$ podpoře jejich profesního vzdělávání a zlepšování odborného výkonu. Mưžeme si povšimnout, že tento princip je zabudován ve všech Standardech jako „osobní závazek“ učitele k nejvyšší možné kvalitě výuky a starostlivosti o žáky, a to jak na rovině osobní reflexe, tak v podpůrném, kolegiálním prostředí pravidelných setkávání se svým mentorem (line manager) v procesu Professional review and 
development (PRD). Není bez zajímavosti, že postup na kariérovém žebříčku jednotlivých Standardů není spojený s vyšším finančním ohodnocením učitele. Naopak, každý registrovaný učitel platí roční př́spěvek $50 \mathrm{E}$.

Ve Skotsku jsou vzdělávací reformy výsledkem širokého politického konsenzu a kontinuity. Přitom je potřeba si připomenout geografickou situaci, kdy jistě není bez obtíží „doručit“ kvalitu i do odlehlých oblastí Skotské vysočiny a vzdálených ostrovů (Shetland Island). Pozoruhodný je významný podíl skotských učitelů na tvorbě kličových školskopolitických dokumentů, včetně Standardů ${ }^{11}$, a důsledné sestavování pracovních skupin ze zástupců (stakeholders) školské praxe, vzdělavatelů učitelů, profesních asociací, představitelů pedagogického výzkumu i vzdělávací politiky na centrální a regionální úrovni. To plně koresponduje s obecným poznáním, že z hlediska funkčnosti profesního standardu je velmi důležité, ,aby byl široce sdílen různými aktéry vzdělávání, aby byl vnitřně přijat samotnými učiteli, aby byl $v$ souladu s tím, jak oni sami chápou podstatu své práce a jak vidí sami sebe jako profesionály“ (Spilková, 2010, s. 74). I když lze způsob implementace Standardů ve Skotsku hodnotit spíše jako „top-down“ proces, tedy iniciovaný centrální autoritou, nutno vyzdvihnout transparentnost a cílevědomé vytváření podmínek pro účinnou participaci učitelů ve všech záležitostech, které se jich dotýkají.

Dalším momentem, na který je vhodné v souvislosti se Standardy poukázat, je proaktivní komunikační strategie skotské vlády, GTCS, ES (Education Scotland, vlivná nezávislá agentura skotské exekutivy) a dalších institucí. Ty prostřednictvím svých internetových stránek poskytují kompletní, relevantní a srozumitelné informace. Samozřejmostí je dostupnost všech klíčových politických dokumentů, zdrojů (např. výstupy z různých analýz, přehledové studie, bibliografické seznamy apod.), ale uživatelům jsou k dispozici i výkladová videa, prezentace, často kladené otázky apod. Na stránkách GTCS např. již nyní běží časomíra, která odpočítává dny, minuty a sekundy do spuštění nového nástroje Professional update ${ }^{12}$. Společným cílem této podpory přitom je, aby skotská společnost měla $k$ dispozici a sdílela jasně zformulovaný soubor profesionálních hodnot, znalostí a jednání učitelů, který přeneseně zajistí pozitivní dopad na žáky a na jejich učení.

Revidované Standardy v platnost od srpna 2013, po dvou a půl letech, a již rok usměrňují školství ve Skotsku. Nemůžeme si nepoložit kritickou otázku, zda nejsou standardy revidovány rychleji, než stihnou být plně implementovány v praxi. Je žrejmé, že učitelé budou potřebovat určitý čas, aby se s novou normou sžili, vzali ji za svou a naučili se ji efektivně využívat pro svůj odborný rozvoj. Př́liš rychlé změny, odlišně strukturovaný model profesionality učitele a formulace vyjádřené „novým“ jazykem, mohou být ve skutečnosti (výhradně podle osobního soudu autora tohoto př́spěvku) pod „rozlišovací schopností“ běžného učitele soustředěného na svoji výuku, a proto př́liš zatěžující, anebo formální. Př́kladem může být The standard for career-long professional learning (2013), který nahradil po necelých čtyřech letech

11 Dostupné z http://www.gtcs.org.uk/web/files/about-gtcs/review-of-professional-standards -groups.pdf.

12 Dostupné z http://www.gtcs.org.uk/professional-update/professional-update.aspx. 
108 The standard for chartered teacher (2009), jemuž dřive předcházel stejnojmenný dokument z roku 2002. Můžeme tedy spekulovat, zda současné skotské Standardy udrží dlouhodoběji krok s měnícími se kontexty vzdělávání a společnosti, aby si na ně učitelé vůbec přivykli. Stejně tak je otázkou, nakolik je potřeba standardy neustále revidovat, abychom konceptualizovali na dobu delší jak několik let, co znamená být učitelem ve Skotsku v 21. století.

S tím souvisí otázky kvality a kvantity. Shora zmíněná Donaldsonova zpráva Teaching Scotland's future (Scottish government, 2010) postulovala 50 doporučení. McCormacova zpráva Advancing professionalism in teaching (Scottish executive, 2011) formulovala 34 doporučení. Důkladná, promyšlená a skutečně účinná implementace takového množství podnětů a $v$ takové šiři nepochybně vyžaduje mimořádně pružnou státní exekutivu s dostatečně silným politickým mandátem. Obdobně samotné Standardy nyní sestávají z desítek indikátorů, např. Standard pro plnou registraci jich obsahuje 96 . Tuto skutečnost trefně komentuje Stronach (in McNally et al., 2007): „Když náboženství stačí deset přikázání, kolik kompetencí je zapotřebí, aby se člověk stal učitelem?“" Tyto úvahy nicméně překračují rámec tohoto př́spěvku.

$\checkmark$ úplném závěru našeho textu považujeme za nutné zmínit, že zdánlivě hladký průběh školské transformace ve Skotsku má i své „spodní proudy“. Na samém začátku příspěvku jsme např. zmínili Curriculum for excellence, nástroj kurikulární reformy, podle něhož se ve Skotsku vyučuje od roku 2010/11. Již před jeho zavedením mnozí představitelé učitelské profese, včetně odborové organizace Educational institute of Scotland (EIS) poukazovali, že formulace dokumentu Curriculum for excellence jsou př́liš vágní, zejména pokud se týká očekávaných vzdělávacích výstupů, což by mohlo vést $k$ nejasnostem, co se vlastně očekává od učitele ve třídě a při posuzování pokroku žáků13. Kvalita učitele tak může být navzdory Standardu snadno zpochybněna, pokud chybí opora $v$ jasně a konkrétně zformulovaném vzdělávacím úkolu pro učitele.

Stejně tak existují kritické ohlasy namířené do samého jádra skotské reformy, jímž je Donaldsonova zpráva Teaching Scotland's future. Např. Smith $(2011$, s. 3) Donaldsonovi vytýká, že „zpráva nepřináší dostatečně široké a flexibilní základy pro budoucí inovace pregraduálního učitelského vzdělávání a naopak je ohrožující ve své omezenosti (narrowness).“

Zatím však uplynula od zavedení nových Standardů př́liš krátká doba, a tak si budeme muset na výzkumné podchycení Budoucnosti skotského učitelství ještě chvíli počkat. Nové zkušenosti přibudou Skotsku rovněž se zavedením inovovaného systému Professional Update (viz výše) v srpnu 2014, se spuštěním Skotské akademie pro vzdělávací leadership ${ }^{14}$ (Voda, 2014) a na národní úrovni pochopitelně Referendum o skotské nezávislosti15 18. září 2014.

13 BBC News, 8. 5. 2009, dostupné z http://news.bbc.co.uk/2/hi/uk_news/scotland/8039474.stm.

14 Dostupné z http://www.scelscotland.org.uk/.

15 Dostupné z http://scotreferendum.com/. 
Děkuji pracovníkům GTCS za čas a ochotu, jež mi věnovali při mém výzkumu.

Jmenovitě: Tom Hamilton, Gillian Hamilton, Zoe Robertson, Norrie McKay, Rosa Murray.

\section{Literatura}

A teaching profession for the 21st century. (2001). Edinburgh: Scottish executive.

Baumfield, I., \& Menter, I. (2008). Curriculum for excellence. Draft experiences and outcomes. Collection, analysis and reporting of data. Interim Report. Glasgow: University of Glasgow. Dostupné z http://www.educationscotland.gov.uk/Images/interim_report_Aug_2008 _tcm4-501212.pdf.

Baumfield, I., Livingston, K., \& Menter, I. (2009). Curriculum for excellence. Draft experiences and outcomes. Collection, analysis and reporting of data. Final report. Glasgow: University of Glasgow. Dostupné z http://www.educationscotland.gov.uk/Images /GUfinalreport_tcm4-539659.pdf.

Centre of study for policies and practices in education (CEPPE). (2013). Learning standards, teaching standards and standards for school principals. Chile: OECD Publishing.

Donaldson, G. (2011). Teaching Scotland's future - Report of a Review of Teacher Education in Scotland. Edinburgh: Scottish government.

European encyclopedia on national education systems (EURYPEDIA). Dostupné z https:// webgate.ec.europa.eu/fpfis/mwikis/eurydice/index.php/United-Kingdom-Scotland: Overview.

General teaching council of Scotland (GTCS). (2012a). The Standards for Registration: mandatory requirements for Registration with the General Teaching Council for Scotland. Edinburgh: GTCS. Dostupné z http://www.gtcs.org.uk/web/Files/the-standards/standards -for-registration-1212.pdf.

General teaching council of Scotland (GTCS). (2012b). The Standard for Career-Long Professional Learning: supporting the development of teacher professional learning. Edinburgh: GTCS. Dostupné z http://www.gtcs.org.uk/web/Files/the-standards/standard-for -career-long-professional-learning-1212.pdf.

General teaching council of Scotland (GTCS). (2012c). The Standards for Leadership and Management: supporting leadership and management development. Edinburgh: GTCS. Dostupné z http://www.gtcs.org.uk/web/Files/the-standards/standards-for-leadership -and-management-1212.pdf.

General teaching council of Scotland (GTCS). (2012d). Code of Professionalism and Conduct. Edinburgh: GTCS.

General teaching council of Scotland (GTCS). (2012e). The Student Teacher Code. Scotland: GTCS.

General teaching council of Scotland (GTCS). (2013). Memorandum on Entry Requirements to Programmes of Initial Teacher Education in Scotland. Edinburgh: GTCS.

Hoyle, E. (1974). Professionality, professionalism and control in teaching. London Education Review, 3(2), 13-19.

Ingvarson, L., Anderson, M., Gronn, P., \& Jackson, A. (2006). Standards for school leadership. A critical review of Literature. Acton (Australia): Teaching Australia.

Kennedy, A., Barlow, W., \& Mac Gregor, J. (2012). Advancing professionalism in teaching? An exploration of the mobilisation of the concept of professionalism in the McCormac Report on the Review of Teacher Employment in Scotland. Scottish Education Review, 44(2), 3-13.

Korthagen, F. (2004). In search of the essence of good teacher: toward a more holistic approach in teacher education. Teacher and Teacher Education, 20(1), 77-97.

McNally, J. Boreham, N., Corbin, B., \& Stronach, I. (2007). Perspectives on Early Professional Learning. Keynote session at the annual konference of the International Society for Teacher Education, Stirling University. 
110 McNally, J., \& Blake, A. (2012). Miss, what's my name? New teacher identity as a question of reciprocial ontological security. Educational Philosophy and Theory, 44(2), 196-211.

National Partnership Group (NPG). (2012). Report to the Cabinet secretary for education and lifelong learning. Edinburgh: Scottish goverment.

Píšová, M. (2011). Pojetí učitelství. In M. Píšová \& K. Duschinská, et al., Mentoring v učitelství (s. 15-38). Praha: PedF UK.

Priestley, M., \& Minty, S. (2012). Developing curriculum for excellence. Summary of findings from research undertaken in a Scottish local authority. Stirling (UK): University of Stirling.

Scottish executive. (2002). The standard for chartered teacher. Edinburgh: Scottish government.

Scottish executive. (2004). Curriculum for excellence. The curriculum review group. Edinburgh: Scottish executive.

Scottish government. (2009). The standard for chartered teacher. Edinburgh: Scottish government.

Scottish government. (2011). Continuing to build excellence in teaching. The Scottish government's response to Teaching Scotland's future. Edinburgh: Scottish government.

Scottish government. (2011). National performance framework. Dostupné z http: / / www.scotland .gov.uk/Resource/Doc/933/0124200.pdf.

Scottish government (2008). Building the curriculum 3: a framework for learning and teaching. Edinburgh: The Scottish Government.

Scottish government (2011). Advancing professionalism in teaching: the report of the review of teacher employment in Scotland. Edinburgh: The Scottish Government.

Smith, I. (2011) Re-visiting the Donaldson review of teacher education: Is creative innovation secured? Scottish Educational Review, 43(2), 17-38.

Spilková, V. (2008). Kvalita učitele a profesní standard. In V. Spilková \& J. Vašutová, et al., Učitelská profese $v$ měnících se požadavcích na vzdělávání (s. 95-103). Praha: PedF UK.

Spilková, V. (2010). Evropské přístupy k pojetí kvality učitele - optikou formálních dokumentů. Pedagogika, 60(3/4), 70-80.

Voda, J. (2013). Ve Skotsku platí od srpna 2013 nové, revidované profesní standardy. Řízení školy, 10, 12-16.

Voda, J. (2014). Ve Skotsku spouští virtuální akademii pro lídry ve vzdělávání. Řízení školy, 11(5), 31-32.

PhDr. Jan Voda, Ph.D., Katedra primární pedagogiky Pedagogická fakulta, Univerzita Karlova v Praze jan.voda@pedf.cuni.cz 
Přiloha 1 Diagramy profesních standardů v různých obdobích zdůrazňující vnitřní sepětí klíčových komponent a finální přesun komponenty „profesní hodnoty“ do jádra Standardu.

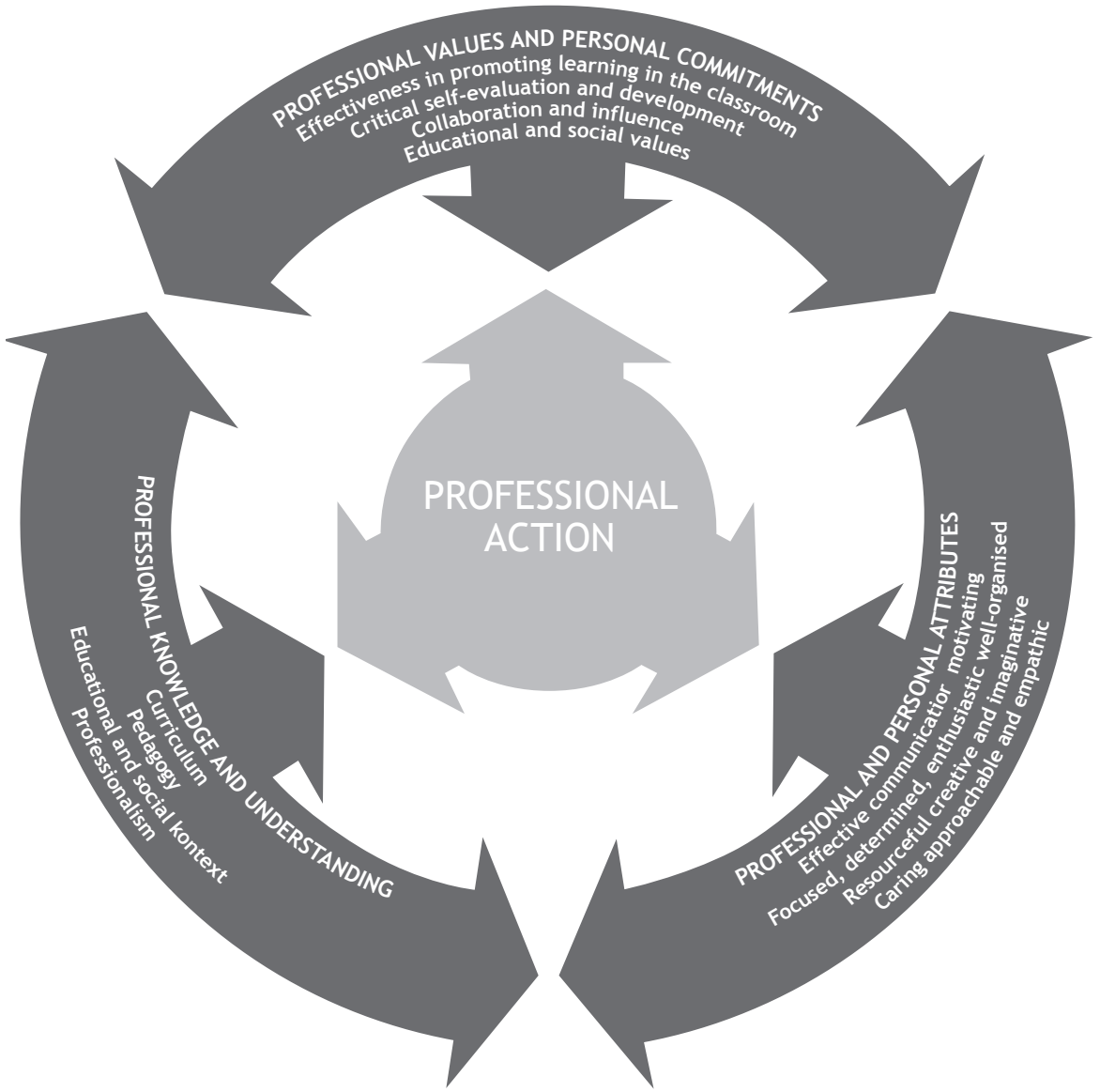

Obrázek P1 The Standard for Chartered Teacher (Scottish Executive 2002, s. 2) 
112

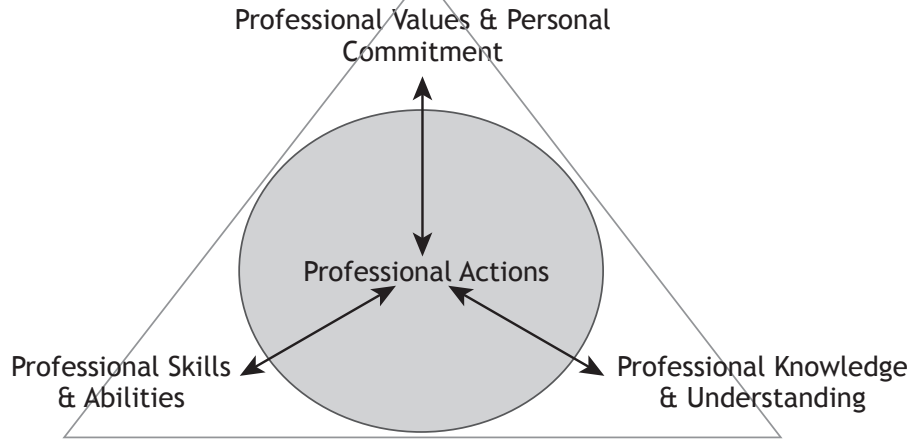

Obrázek P2 The Standard for Chartered Teacher (Scottish Government, 2009, s. 2)

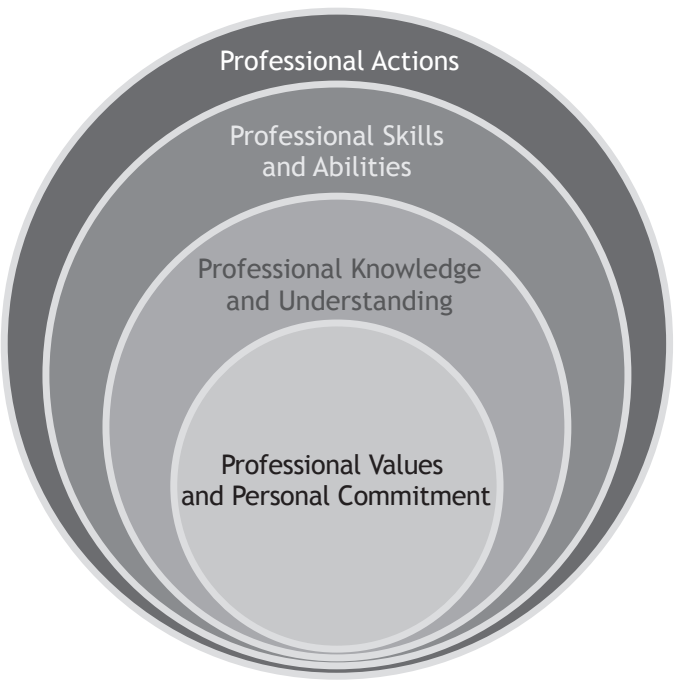

Obrázek P3 The Standard for Career-Long Professional Learning (GTSC, 2012b, s. 3) 